\section{Hubungan hukum antara pt. Bank tabungan negara (persero) tbk. Kcp sutomo di kota medan dengan pengembang dan nasabah peminjam pada kredit pemilikan rumah inden Oleh :}

Azansyah Hashif, Bismar Nasution, Sunarmi, Mahmul Siregar ${ }^{1}$

\section{hashifazansyah@gmail.com}

\section{Abstract}

People's Housing Credit (KPR) by indent, as the product of PT Bank Tabungan Negara (Persero), is buying houses which have not been built by contractors by credit system. The houses will be built when the contract is signed by the prospective buyers who have ordered the houses. The Bank is vulnerable to the risk of developers' default in building the houses; it is also take the risk of the default the debtors who are not able to pay the installment while the houses are being built. It is necessary to study the legal realationship in giving KPR by indent so the research was done at PT Bank Tabungan Negara (Persero), Tbk, KCP Sutomo, Medan.

The research used juridical normative method with descriptive analytic approach, supported by primary data. The data were gathered by conducting library research, field study, documentation, and interview and analyzed by using qualitative method. The legal relationship between $P T$ Bank Tabungan Negara (Persero) Tbk KCP Sutomo with developers and borrowing customers in providing indent housing loans (KPR) is a form of tripatrit legal relationship, because of the cooperation agreement between Bank BTN and the developer and provision of credit between Bank BTN. and borrowing customers where the three parties each have rights and obligations.

1 Program Studi Magister IImu Hukum Fakultas Hukum Universitas Sumatera Utara
Keywords: people's housing credit, indent, prudential principle, bank

\section{Abstrak}

Kredit Pemilikan Rumah (KPR) inden merupakan produk PT. Bank Tabungan Negara (Persero) berupa kredit pembelian rumah atas rumah yang belum dibangun oleh pengembang. Rumah akan dibangun oleh pengembang dengan memerintahkan kontraktor setelah ada pihak pembeli. KPR inden menjadikan posisi bank syarat dengan risiko terutama karena pada saat penandatanganan perjanjian kredit, rumah dalam kondisi belum dibangun. Bank menjadi rawan risiko atas wanprestasinya pengembang dalam membangun rumah, demikian pula terhadap wanprestasinya debitur karena macet tidak mampu membayar angsuran KPR indennya yang pada saat itu masih dalam periode pembangunan. Perlu dilakukan kajian mengenai hubungan hukum dalam pemberian KPR secara inden pada PT. Bank Tabungan Negara (persero) Tbk. KCP Sutomo di Kota Medan.

Metode penelitian yang digunakan adalah penelitian hukum normatif dengan dukungan data primer. Penelitian ini merupakan penelitian deskriptif analitis dengan tehnik pengumpulan dilakukan melalui studi pustaka dan studi lapangan. Alat pengumpulan data menggunakan studi dokumen dan pedoman wawancara. Analisis data dilakukan dengan metode analisis data kualitatif. Hubungan hukum antara PT Bank Tabungan Negara (Persero) Tbk KCP Sutomo dengan developer dan nasabah peminjam dalam pemberian Kredit Pemilikan Rumah (KPR) inden adalah bentuk hubungan hukum yang tripatrit, karena adanya perjanjian kerja sama antara bank BTN dengan developer dan pemberian kredit antara bank BTN dan nasabah peminjam dimana ketiga pihak tersebut masing-masing memiliki hak dan kewajiban.

Kata kunci: hubungan hukum, bank, kredit perumahan rakyat, inden 
Media Komunikasi dan Informasi Hukum dan Masyarakat

\section{Pendahuluan}

\section{A. Latar Belakang}

Kredit Pemilikan Rumah (KPR) inden adalah suatu bentuk pelayan kredit perumahan dimana rumah yang baru akan dibangun oleh kontraktor melalui perintah dari pengembang perumahan (developer) setelah ada pembelinya. Fasilitas KPR inden ini memberikan kemudahan bagi developer dalam menjalankan usahanya dikarenakan tidak perlu adanya pengeluaran modal yang banyak untuk membangun suatu rumah yang belum ada pembelinya.

Program KPR inden melibatkan bank, pembeli dan pengembang (developer) yang terjalin dalam suatu perjanjian yang mengikat secara hukum. Bank dengan pembeli terikat dalam suatu hubungan hukum perjanjian kredit sedangkan antara bank dan developer memiliki perikatan berdasarkan suatu perjanjian kerjasama. Sebagai suatu bentuk hubungan hukum perjanjian kredit, maka permasalahan kredit macet atau ketidakmampuan dari debitur (pembeli rumah inden) untuk melanjutkan pembayarannya terhadap KPR inden tersebut serta adanya developer yang tidak memenuhi perjanjian kerja sama dengan bank dalam memenuhi kewajibannya dalam pembangunan rumah inden, merupakan masalah-masalah yang timbul dari kegiatan operasional pelayan KPR inden. ${ }^{2}$

Pembiayaan rumah inden melalui kredit perbankan pada prinsipnya melemahkan posisi bank sebagai lembaga yang membiayai pembelian rumah inden tersebut. Hal ini dikarenakan pada saat penandatanganan akta perjanjian kredit berikut perjanjian accessoir

${ }^{2}$ Suhardi Gunarto. Resiko Dalam Pemberian Kredit Perbankan. Jurnal hukum Pro Justisia, Volume 24 Nomor 2 2010, hal. 11 lainnya kondisi rumah masih sebuah tanah kosong (belum adanya rumah yang dibangun). Keadaan ini sangat rawan bagi bank terhadap wanprestasinya developer untuk memenuhi janjinya dalam membangun rumah sesuai dengan jangka waktu yang telah disepakati. Demikian pula dengan debitur yang wanprestasi yaitu mengalami kemacetan dalam melakukan pembayaran angsuran dari KPR inden-nya yang pada saat itu masih dalam periode pembangunan. $^{3}$

PT Bank Tabungan Negara KCP Sutomo Kota Medan (BTN Sutomo Medan) merupakan salah satu bank yang menyalurkan kredit KPR inden kepada masyarakat. Masyarakat dapat mengajukan kredit kepada BTN untuk memenuhi kebutuhan hidupnya terutama dalam bidang perumahan. Mengingat berbagai risiko bank dalam KPR rumah inden, maka perlu dilakukan pembahasan untuk mengetahui penerapan prinsip kehati-hatian dalam pemberian KPR secara inden oleh BTN Sutomo Medan.

\section{B. Rumusan Masalah}

Berdasarkan latar Belakang diatas penulis tertarik untuk membahas tentang bagaimana Hubungan Hukum Antara PT. Bank Tabungan Negara (Persero) Tbk. KCP Sutomo di Kota Medan Dengan Pengembang dan Nasabah Peminjam Pada Kredit Pemilikan Rumah Inden.

\section{Metode Penelitian}

Penelitian ini mengelaborasi metode penelitian hukum normatif dan penelitian hukum

${ }^{3}$ Agus Santoso. Maintaining Financial Stability: Indonesia's Experience in Preventing and Handling Financial Crisis. Buletin Hukum Perbankan dan Kebanksentralan, Volume 8 Nomor 2 2010, hal. 5. 
Media Komunikasi dan Informasi Hukum dan Masyarakat

empiris. Metode penelitian hukum normatif digunakan karena objektif dari penelitian adalah untuk melakukan analisis yang mendalam terhadap norma hukum yang terkandung dalam perundang-undangan nasional di bidang perbankan yang berkaitan langsung maupun tidak langsung dengan prinsip kehati-hatian perbankan. Sedangkan metode penelitian hukum empiris digunakan untuk menganalisis penerapan norma hukum oleh subyek hukum dalam hal ini penerapan prinsip kehati-hatian oleh BTN KCP Sutomo Medan dalam memberikan KPR atas rumah inden.

II. Pembahasan Tentang Hubungan Hukum Antara PT. Bank Tabungan Negara (Persero) Tbk. KCP Sutomo di Kota Medan Dengan Pengembang dan Nasabah Peminjam Pada Kredit Pemilikan Rumah Inden

Hubungan hukum antara badan usaha bank (kreditor) dengan nasabah peminjam (debitur) diikatkan melalui suatu perjanjian tertulis. Bahkan di dalam berbagai peraturan pelaksanaan UUP yang diterbitkan oleh Bank Indonesia dengan tegas dikemukakan, bank tidak diperbolehkan untuk memberikan kredit tanpa surat perjanjian secara tertulis. Perjanjian tertulis antara kreditor dan debitor pada umumnya sudah dalam bentuk kontrak standar.

Perjanjian kredit tersebut dilihat dan dipelajari lebih rinci, terlihatlah bahwa perjanjian kredit itu terbagi dalam dua bagian yaitu perjanjian induk dan perjanjian tambahan. Perjanjian induk mengatur hal-hal pokok, sedangkan perjanjian tambahan menguraikan apa yang kemudian diatur dalam perjanjian pokok.
Dalam Pasal 1313 KUHPdt dikemukakan bahwa suatu perjanjian adalah suatu perbuatan dimana satu orang atau lebih mnegikatkan dirinya terhadap satu orang lain atau lebih. Kemudian selanjutnya, dalam Pasal 1320 KUHPdt dijelaskan untuk sahnya suatu perjanjain diperlukan 4 (empat) syarat, yaitu:

1. Sepakat mereka yang mengikatkan dirinya;

2. Kecakapan untuk membuat suatu perikatan;

3. Suatu hal tertentu, dan

4. Suatu sebab yang halal.

Sementara itu di dalam Pasal 1338 ayat (1) KUHPdt dijelaskan, semua perjanjian yang dibuat secara sah berlaku sebagai undangundang bagi mereka yang membuatnya. Berdasarkan dari ketentuan yang disebutkan di atas, bagi para pihak yang akan menandatangani suatu perjanjian khususnya perjanjian kredit perlu mempelajari dengan cermat apa hak dan kewajibanya yang harus dipenuhi jika perjanjia kredit sudah ditandatangani. Hal ini penting dikarenakan mengingat dalam perjnajian kredit sarat dengan klausul. Artinya, ada sejumlah persyaratan yang harus dipatuhi oleh debitur. Bila tidak dipatuhi akan mendapatkan konsekeunsi antara lain berupa denda yang tentunya akan merugikan debitur.

Salah satu bank yang menyediakan dana dalam pemberian fasilitas KPR inden adalah bank BTN melalui sebuah perjanjian. Perjanjian ini dilakukan dalam bentuk kerja sama antara bank BTN dan developer. BTN dan nasabah peminjam dalam akad kredit dituangkan dalam bentuk tertulis yang ditandatangani oleh pihak-pihak berwenang. Perjanjian kerjasama dan akad kredit dalam bentuk tertulis mempunyai guna untuk menghindari berbagai macam risiko yang tidak 
Media Komunikasi dan Informasi Hukum dan Masyarakat

terduga terhadap kejadian-kejadian dikemudian hari.

Pada prinsipnya perjanjian tertulis ini dilakukan sebagai pengingat bagi kedua belah pihak terhadap hak dan kewajiban yang seharusnya dilakukan dan larangan untuk tidak melakukan hal-hal yang disebutkan dalam perjanjian tersebut. Bentuk perjanjian kerjasama antara bank BTN dengan developer serta akad kredit bank BTN dengan nasabah peminjam dalam pemberian KPR inden adalah di bawah tangan pada awalnya dan akan dilakukan secara notarial untuk selanjutnya. Dengan demikian akad kredit dan perjanjian kerjasama antara bank BTN dengan developer dan nasabah peminjam dibuat dalam bentuk akta autentik, yang di dalam hal ini dibuat oleh notaris yang berwenang. ${ }^{4}$

Suatu perjanjian dapat diartikan sebagai suatu perhubungan hukum mengenai harta benda antara 2 (dua) pihak atau lebih dimana suatu pihak dianggap berjanji untuk melakukan sesuatu hal, sedangkan pihak lain berhak menuntut pelaksanaan janji itu".

Pembelian rumah inden melalui KPR bank terutama KPR inden BTN diawali dengan perjanjian jual beli rumah antara konsumen dengan developer ialah perikatan yang lahir karena persetujuan, oleh karena perjanjian itu sendiri tidak akan ada apabila para pihak tidak menghendaki atau tidak dapat mencapai suatu kesepakatan. Proses tersebut kemudian dilanjutkan dengan dibuatnya perjanjian kredit antara pembeli rumah (debitur) dengan BTN sebagai pihak yang pembiaya pembelian rumah itu, berikut dengan pembebanan rumah tersebut dengan lembaga jaminan hak tanggungan. Perjanjian kredit merupakan perjanjian yang sudah baku, artinya perjanjian yang sudah disusun dan dibuat oleh pihak bank dengan sedemikian rupa.

Didalam konstruksi hukum yang demikian maka untuk selanjutnya si pembeli merupakan debitur dari BTN dan BTN adalah kreditur, serta rumah dan tanah milik debitur akan menjadi jaminan terhadap pelunasan KPR BTN selama jangka waktu yang diperjanjikan. Maka daripada itu terjadinya tanggung jawab hukum antara developer dengan bank ialah karena timbulnya suatu peristiwa hukum yang lahir melalui perjanjian antara bank dengan debitur dengan ketentuan bahwasanya rumah yang dibeli tersebut oleh debitur tersebut masih inden atau masih tanah kosong sehingga developer bertanggung jawab penuh terhadap penyelesaian pembangunannya rumah yang dibiayai oleh bank sebagai penyedia dana. Dengan demikian terjadilah hubungan hukum yang bersifat tripatrit antara BTN dengan pihak developer dan nasabah peminjam sebagaimana dimaksud di atas sehingga dalam hal ini masing-masing pihak mempunyai hak dan kewajiban masing-masing dan harus bertanggung jawab penuh untuk menyelesaikan perjanjian yang telah disepakati bersama.

\section{Penutup}

\section{A. Kesimpulan}

Penerapan standar kehati-hatian dalam pemberian KPR secara inden oleh PT. Bank Tabungan Negara (persero) Tbk. KCP Sutomo di Kota Medan meliputi permohonan kredit, verifikasi dan analisa, persetujuan kredit; persiapan akad kredit; serta permohonan pencairan kredit. Dalam prakteknya Bank BTN menerapkan prinsip kehati-hatian dalam pelayanan KPR inden, pertama adalah mengatur pengendalian risiko berupa kewajiban 
Media Komunikasi dan Informasi Hukum dan Masyarakat

penyusunan perjanjian kerjasama dengan pengembang, pembelian kembali agunan atau buy back, penilaian agunan oleh jasa penilai properti beserta kewajiban perjanjian kerjasamanya, serta penyelesaian kredit bermasalah. Kedua adalah petunjuk pelaksanaan LTV dan pelaksanaan Kredit inden untuk KPR. Prosedur-prosedur yang dilakukan oleh Bank BTN KCP Sutomo sebenarnya telah dilakukan sesuai dengan prinsip kehati-hatian untuk menghindari wanprestasi debitur dan developer akan tetapi penerapan dari prinsip kehati-hatian kurang didukung oleh kompleksitas informasi yang diyakini dapat mengurangi risiko wanprestasi debitur dan dapat mengurangi risiko wanprestasi developer. ${ }^{5}$

\section{B. Saran}

Disarankan kepada pihak perbankan, agar mempertegas tugas pihak internal perbankan di dalam melakuan pengawasan dan kontrol terhadap pemberian KPR secara inden pada pihak debitur dan pihak developer sebagaimana penerapan prinsip kehati-hatian ini telah diamanatkan dalam Pasal 2 UndangUndang Nomor 10 Tahun 1998 Tentang Perbankan serta Pasal 8 ayat 1 UndangUndang Nomor 10 Tahun 1998 Tentang Perbankan dimana bank dalam memberikan kredit harus melakukan uji analisis yang mendalam atas itikad baik dan serta kemampuan nasabah debitur untuk melunasi utangnya sesuai dengan apa yang telah diperjanjikan. Hal ini karena bank adalah Lembaga yang menghimpun dana milik masyarakat, sehingga perbankan haruslah menjalankan kegiatan penyaluran

${ }^{5}$ Wawancara dengan Kepala Cabang Bank BTN KCP Sutomo Medan, PT Bank Tabungan Negara (Persero) TBK KCP Sutomo di Kota Medan. Pada tanggal 26 Juli 2020 perkreditannya berpedoman prinsip kehatihatian yang akan meningkatkan kinerja perbankan dan kepercayaan masyarakat dan usaha perbankan.

\section{Daftar Pustaka}

\section{A. Buku}

Abdulkadir Muhammad, Hukum Perusahaan Indonesia. Citra Aditya Bakti, Bandung, 2010.

Agus Santoso. Maintaining Financial Stability: Indonesia's Experience in Preventing and Handling Financial Crisis. Buletin Hukum Perbankan dan Kebanksentralan, Volume 8 Nomor 2 2010.

Gatot Supramono, Perbankan dan Masalah Kredit Suatu Tinjauan di Bidang Yuridis, Rieneka Cipta., Jakarta, 2009.

Iswi Hariyani Restrukturisasi Dan Penghapusan Kredit Macet, Kenapa Perbankan Memanjakan Debitur Besar Sedangkan Usaha/Debitur Kecil Dipaksa. Alex Media Komputindo, Jakarta, 2010.

R. Subekti, Hukum Perjanjian, PT. Intermasa. Jakarta, 2005.

Suhardi Gunarto, Resiko Dalam Pemberian Kredit Perbankan, Jurnal hukum Pro Justisia,Volume 24 Nomor 2, 2010.

Wawancara dengan Kepala Cabang Bank BTN KCP Sutomo Medan, PT Bank Tabungan Negara (Persero) TBK KCP Sutomo di Kota Medan. Pada tanggal 26 Juli 2020. 
Media Komunikasi dan Informasi Hukum dan Masyarakat

SOP Pemberian Kredit PT Bank Tabungan Negara (Persero) Tbk KCP Sutomo. 2020.

\section{B. Peraturan Perundang-Undangan}

Undang-Undang Nomor 10 Tahun 2008 Tentang Perbankan

C. Internet

BTN. "Pembiayaan Perumahan KPR BTN Indent",https://www.btn.co.id/id/SyariahHome/Syariah-Data-Sources/ProductLinks-Syariah/Produk-

BTNSyariah/pembiayaan/PembiayaanPerumahan/KPR--BTN-Indent-iB (diakses pada tanggal 1 Mei 2020, Pukul : 10.00 WIB) 